\title{
New methods in optical diagnostics on production engines with only minor modifications
}

\begin{abstract}
The aim of this paper is to demonstrate the performance of micro-invasive optical diagnostics as advanced tools in the development process of modern direct-injection (DI) gasoline engines. The use of endoscopes and optical probes minimise the mechanical modifications on the engine necessary to achieve the optical access to the combustion chamber. No expensive optical engines with large optical windows are required but only small holes of about $10 \mathrm{~mm}$ in the cylinder head or in a plate between cylinder head and cylinder liner are used to apply laser diagnostics. Basic in-cylinder phenomena, such as the formation of the flow field, the penetration of the spray at high fuel pressure, the interaction of spray and flow, the formation of an ignitable mixture and the start of combustion are analysed in detail. High-power solid-state pulsed lasers emitting ultraviolet or green light, state-of the-art high-speed colour video cameras, and newly designed optical probes were used for the investigations. Selected results from current research and development work demonstrate the capability of micro-invasive techniques and pinpoint how the design of the combustion process benefits from these experimental investigations.
\end{abstract}

Key words: optical diagnostics, endoscopes, optical probes, combustion process development

\section{Nowe metody diagnostyki optycznej silników produkcyjnych wymagające nieznacznych modyfikacji}

\begin{abstract}
Celem artykułu jest przedstawienie możliwości małoinwazyjnych metod diagnostyki optycznej jako zaawansowanych narzędzi w rozwoju nowoczesnych silników benzynowych z wtryskiem bezpośrednim (DI). Zastosowanie endoskopów $i$ obserwacji optycznych minimalizuje konieczność mechanicznych modyfikacji w celu uzyskania dostępu optycznego do komory spalania. W takiej sytuacji nie jest konieczne wykorzystywanie kosztownych silników do specjalistycznych badań optycznych (tzw. silników transparentnych), wyposażonych w okna optyczne o dużych rozmiarach, lecz stosowane sq jedynie otwory o niewielkiej średnicy, ok. $10 \mathrm{~mm}, w$ głowicy cylindrowej lub w płycie umieszczanej pomiędzy głowica a tuleja do zastosowania diagnostyki laserowej. W ten sposób są szczegółowo analizowane podstawowe zjawiska w cylindrze, jak tworzenie się pola przepływów, rozprzestrzenianie się strugi paliwa przy dużym ciśnieniu wtrysku, wzajemne oddziaływanie pomiędzy struga paliwa i przeptywem czynnika, tworzenie się mieszanki zapłonowej na początku spalania. Do badań wykorzystuje się impulsowe lasery dużej mocy, promieniujace świattem ultrafioletowym lub zielonym na ciele stałym, wspótczesne kamery kolorowe do szybkiego filmowania i najnowszej konstrukcji sondy. Wybrane wyniki z aktualnych badań i prac rozwojowych wykazuja przydatność małoinwazyjnych metod diagnostyki optycznej i wskazuja, jak można wykorzystać badania optyczne przy projektowaniu procesu spalania.
\end{abstract}

Słowa kluczowe: diagnostyka optyczna, endoskopy, sondy optyczne, ksztaltowanie procesu spalania

\section{Introduction}

The reduction of exhaust gas emissions and fuel consumption is the major target for the development of new engine combustion processes. An important step has been made by applying direct fuel injection to gasoline engines. From the beginning, the development of FSI direct-injection (DI) gasoline engines at Volkswagen was strictly supported by means of optical diagnostics and CFD-simulations. Basic in-cylinder phenomena, such as the formation of the flow field, the penetration of the spray at high fuel pressure, the interaction of spray and flow and the formation of an ignitable mixture were analysed in detail and thereby significant conclusions were drawn to further optimise the combustion process. For more details see e.g. Hentschel et al. [1].

In the past, so called "transparent engines" with large optical access to the combustion chamber via windows in the piston bottom and the cylinder liner have been used to assist research and development activities. Many research

\section{Wprowadzenie}

Głównym celem nowych procesów spalania w silniku spalinowym jest zmniejszenie emisji spalin i zużycia paliwa. Ważnym krokiem w tym kierunku było zastosowanie wtrysku bezpośredniego w silnikach benzynowych. Rozwój silników benzynowych $\mathrm{z}$ wtryskiem bezpośrednim FSI w firmie Volkswagen od początku ich powstania był wspomagany diagnostyką optyczną i symulacją CFD (Computational Fluid Diagnostics). Podstawowe zjawiska w cylindrze, takie jak tworzenie się pola przepływów, rozprzestrzenianie się strugi paliwa przy dużym ciśnieniu wtrysku i tworzenie się mieszanki zapłonowej były szczegółowo analizowane i dzięki temu sformułowane zostały ważne wnioski do dalszej optymalizacji procesu spalania. Więcej informacji na ten temat można znaleźć np. w pracy Hentschla i in. [1].

W przeszłości do prac badawczych i rozwojowych stosowano tzw. silniki transparentne, mające dostęp optyczny do komory spalania przez dużych rozmiarów okna umiesz- 
labs all around the world operate these types of engines for their basic studies of in-cylinder phenomena. An excellent overview is given by Zhao et al. [2].

If the shape of the piston has to remain unchanged a more-or-less large glass ring is placed between the cylinder head and the cylinder to allow a multiple optical access to the combustion chamber from different sides. In another design optical access is achieved by a window in the piston bottom which allows large scale optical access via a mirror inserted into the elongated piston. The latter set-up was often used for diesel engines $\left(\mathrm{TDI}^{\circledR}\right)$ where most of the combustion chamber is located in a piston bowl.

Unfortunately, the use of these types of engines is limited to engine operation at low or medium speed and load due to mechanical restrictions given by the higher piston mass and the optical windows, and their thermo-dynamical behaviour is different compared to the related standard production engines.

The new challenges in engine research and development result in high demands on the performance of optical diagnostics. It is a prerequisite for the optical access to the combustion chamber that the in-cylinder processes should remain as unchanged as possible even at high engine speed and full load operation. The use of endoscopes and optical probes minimise the mechanical modifications necessary to achieve the optical access. Only small holes of 5 to $10 \mathrm{~mm}$ in the cylinder head or cylinder liner are required to apply laser diagnostics such as particle-image-velocimetry (PIV) for flow measurements, Mie-scattering for spray investigation, or laser-induced fluorescence (LIF) studies of mixture distribution. Highly resistant quartz or sapphire windows protect the sensitive endoscopes against the high temperature and pressure inside the combustion chamber. The use of endoscopes reduces costs and the expenditure of working hours in setting up the test engines.

In addition, a newly developed optical sensor measures the local fuel vapour density at the position of the spark plug. By this probe mounted in the spark plug hole together with a modified spark plug the temporal development of the airfuel mixture is examined and thereby the injection timing and the combustion stability can be optimised.

The aim of this paper is to demonstrate the performance of micro-invasive optical diagnostics as advanced tools in the development process of modern DI gasoline engines and to discuss the advantages, disadvantages and challenges of endoscopic techniques. The examples were taken from research and development activities from different FSI engines.

\section{Micro-invasive optical access to Engines}

The new approach is to modify series production engines by adding special small optical accesses. The position, direction and the number of accesses is determined both by the available space in the cylinder head and the measurement technique to be used.

For the visualisation of flame luminescence normally one optical access with direct view towards the flame will be sufficient while line-offsite absorption measurements usually require two small opposing openings. For light-sheet czone w koronie tłoka i tulei cylindrowej. Wiele laboratoriów badawczych na świecie stosowało taki rodzaj silników w badaniach podstawowych zjawisk wewnątrzcylindrowych. Doskonały ich przegląd podaje Zhao i in. [2].

Jeżeli kształt tłoka musi pozostać niezmieniony, odpowiednio duży pierścień szklany umieszcza się pomiędzy głowicą silnika a blokiem silnika, żeby umożliwić wielostronny dostęp optyczny do komory spalania. W innych konstrukcjach dostęp optyczny zapewnia okno w koronie tłoka, co umożliwia pełnowymiarowy dostęp optyczny przez lustro wstawione do wydłużonego tłoka. Takie rozwiązanie było często stosowane w silnikach o ZS (TDI $\left.{ }^{\circledR}\right)$, w których większa część komory spalania jest umieszczona w zagłębieniu tłoka.

Niestety, wykorzystanie tego rodzaju silników jest ograniczone do pracy na małej i średniej prędkości obrotowej i średnim obciążeniu ze względu na ograniczenia mechaniczne wynikające $\mathrm{z}$ większej masy tłoka i okna szklanego, a ich właściwości cieplne i dynamiczne różnią się od właściwości odpowiednich silników produkcji seryjnej.

Nowe oczekiwania wynikające z badań i rozwoju silników skutkują większymi wymaganiami dotyczącymi diagnostyki optycznej. Warunkiem wstępnym badań optycznych komory spalania jest niezakłócanie procesów wewnątrzcylindrowych, nawet przy dużej prędkości obrotowej i obciążeniu silnika. Zastosowanie endoskopów i sond optycznych minimalizuje zmiany konstrukcyjne konieczne do uzyskania dostępu optycznego. Otwory o niewielkich średnicach 5 do $10 \mathrm{~mm}$ w głowicy lub tulei cylindrowej są wymagane do zastosowania diagnostyki laserowej, takiej jak: PIV (particle-image-velocimetry) do pomiarów przepływu, rozpraszanie Mie do badań strugi paliwa lub studiów nad rozkładem mieszanki z wykorzystaniem techniki LIF (laser-induced fluorescence). Bardzo wrażliwe endoskopy osłaniane są przed działaniem wysokiej temperatury i ciśnienia w komorze spalania odpornymi oknami kwarcowymi lub szafirowymi. Zastosowanie endoskopów zmniejsza koszty i czas pracy przystosowania silników do badań.

Dodatkowo, nowo opracowany czujnik optyczny umożliwia pomiar miejscowego stężenia par paliwa w obszarze świecy zapłonowej. Dzięki umieszczeniu czujnika w zmodyfikowanej świecy zapłonowej określane jest bieżące tworzenie mieszanki paliwowo-powietrznej i w ten sposób może być optymalizowany czas wyprzedzenia wtrysku i powtarzalność spalania.

Celem tego artykułu jest przedstawienie możliwości małoinwazyjnych metod diagnostyki optycznej jako zaawansowanych narzędzi w rozwoju nowoczesnych silników benzynowych z wtryskiem bezpośrednim oraz przedyskutowanie ich zalet i wad w stosunku do techniki endoskopowej. Przykłady zostały zaczerpnięte z prac badawczych i rozwojowych różnych silników typu FSI.

\section{Małoinwazyjny dostęp optyczny do silników}

Nowe podejście do badań optycznych polega na wprowadzeniu niewielkich zmian konstrukcyjnych do silnika seryjnego przez dodanie specjalnego dojścia optycznego małych rozmiarów. Miejsce, kierunek i liczba dojść optycznych wynika z miejsca dostępnego w głowicy cylindrowej i techniki pomiarowej, która ma być zastosowana. 
techniques two separate optical accesses for illumination and detection are needed, which should enclose an angle of $90^{\circ}$. For measurements with incident light, the orientation between the illumination and detection direction is not too critical, but to reduce the negative influences from reflections a $90^{\circ}$ set-up is preferred.

A common means of obtaining horizontal optical accesses in modern four-valve SI engines is via bores located either under the intake and exhaust ports or at the front of the cylinder head as shown in Fig. 1. The implementation of vertical accesses is more difficult, since most of the available space in the cylinder head is consumed by the valves, spark plug, and the injector respectively. Nevertheless use of this type of access to the combustion chamber is wide spread, as it is common practice for pressure indication using pressure sensors. Since window fouling during measurements is normally unavoidable, a housing design that can be detached from the cylinder head to allow easy window cleaning is highly desirable. Likewise, when designing the optical accesses the possible interference of bolt-on parts such as the intake and exhaust manifolds and the cam belt drive must be taken into consideration. Often these encroach upon the line of sight of the openings and can therefore interfere with the use of endoscopes.

A back door to circumvent these problems is to mount a small spacer plate between cylinder head and cylinder which covers the optical accesses. Of course, the piston has to be extended by the height of this plate. The design looks similar to the sketch in Fig. 1 left (see also Knapp et al. [3] for an early version).

The second approach is to use existing combustion chamber openings as accesses for optical measurements. For SI engines the spark plug hole can be used and when running the engine under motored conditions the entire diameter of the spark plug bore is available; see Richter et al. [4] for early LIF studies. However, if the ability to fire the engine must be preserved a special measurement spark plug must be used. Today a wide range of optical fibre spark plug adapters are available with various numbers of fibres, viewing angles and fields of view to suit different applications.
Zwykle do wizualizacji luminancji płomienia wystarcza jeden dostęp optyczny w kierunku płomienia, natomiast pomiary absorpcji oświetlenia zewnętrznego wymagają dwóch małych otworów położonych naprzeciw siebie. W technikach z oświetleniem płaszczyznowym potrzebne są dwa niezależne dostępy optyczne, które powinny tworzyć kąt $90^{\circ}$. W pomiarach z wykorzystaniem oświetlenia nieciągłego wzajemne położenie kierunków oświetlania i pomiarów promieniowania nie jest tak ważne, choć kąt $90^{\circ}$ jest zalecany w celu zmniejszenia negatywnego wpływu odbić światła.

Typowym sposobem uzyskania poziomego dostępu optycznego w nowoczesnych czterozaworowych silnikach o ZI jest dojście przez otwory umieszczone pod zaworami dolotowymi i wydechowymi, lub z przodu głowicy, jak to pokazano na rys. 1. Zastosowanie dojścia pionowego jest trudniejsze, ponieważ większość powierzchni komory spalania jest zajęta przez zawory, świecę zapłonową i wtryskiwacz. Jednakże zastosowanie takiego rodzaju dostępu optycznego do komory spalania jest szeroko rozpowszechnione, podobnie jak przy indykowaniu z użyciem czujników ciśnienia.

Ponieważ zanieczyszczenie okna podczas pomiarów jest zwykle nie do uniknięcia, pożądana jest taka konstrukcja obsady okna, aby mogło ono być łatwo demontowane w celu czyszczenia. Podobnie przy projektowaniu dostępu optycznego należy wziąć pod uwagę możliwe kolidowanie takich elementów, jak przewody dolotowe i wylotowe oraz napęd pasowy wałka rozrządu. Często te przeszkody na linii optycznej otworów utrudniają użycie endoskopów. Sposobem uniknięcia tych problemów jest zamontowanie małej podkładki dystansowej pomiędzy głowicą a korpusem silnika, która obejmuje dostęp optyczny. Oczywiście, tłok musi być wydłużony o grubość tej podkładki. Konstrukcja wygląda podobnie do przedstawionej na rys. 1 po lewej stronie (zob. także wersja wcześniejsza: Knapp i in. [3]).

Inne podejście do pomiarów optycznych polega na wykorzystaniu otworów istniejących w komorze spalania. W silnikach o ZI może być wykorzystany otwór na świecę zapłonową, a jeżeli silnik jest napędzany z zewnątrz, wówczas można wykorzystać całą powierzchnię otworu (por. Richter i in. [4]) w odniesieniu do wczesnych pomiarów LIF. intake port/zawór dolotowy

exhaust port/zawór wylotowy spark plug/świeca zapłonowa cylinder-head/głowica cylindra gasket/uszczelka podgłowicowa bonded cylinder-head bushing/dostęp przez głowice

pressure/ciśnienie

sensor/czujnik

optical access/dostęp optyczny

Fig. 1. Example-positions and orientations of optical accesses for the application of endoscopes to engines

Rys. 1. Przyklady miejsca i kierunków dostępu optycznego dla endoskopów $w$ silnikach spalinowych
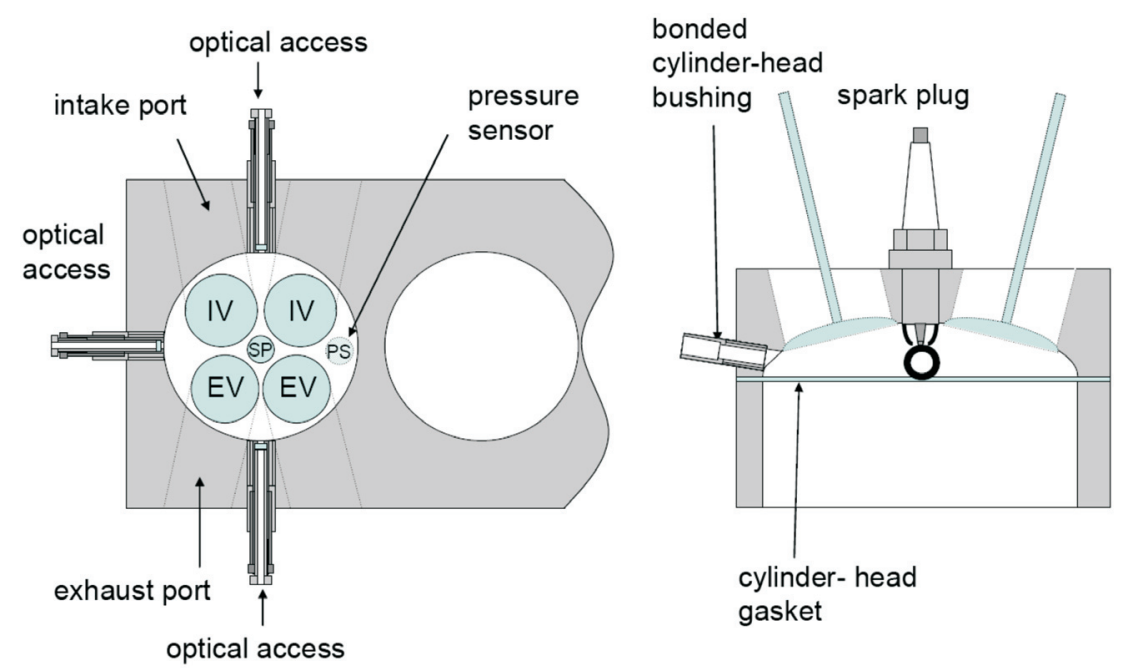
In most cases fibre-based detectors are used to detect spontaneous emission from the flame or the spark inside the combustion chamber. Recent developments, however, include absorption measurements and LIF based measurements through fibres that are incorporated into a spark plug.

The main advantage of using existing openings is the ease with which an optical access can be realised, since measurement spark plugs can be obtained from many manufacturers of metrology equipment. Furthermore, measurements can be taken in any or all of the cylinders simultaneously and are not limited to cylinders having a favourable position, for example at the end of a bank. One disadvantage is that the location of the access is determined by the position of the spark, and normally only one access per cylinder is possible.

\section{Optical diagnostics for combustion process development}

Flow field investigations in the cylinder are often made by PIV and many applications were reported on engines with large scale optical access. Endoscopic PIV has been introduced by LaVision as a commercial product around the year 2001. Dierksheide et al. [5] have published a comprehensive paper with details about the design of the laser endoscope for illumination and the camera endoscope for taking the PIV images.

A typical set-up for endoscopic PIV on a DI gasoline engine is shown in Fig. 2. Both endoscopes have an outer diameter of $8 \mathrm{~mm}$ and fit into the window adapters described in the previous section. While seeding is performed by oil droplets produced by an aerosol generator no damage occurs on the engine. A problem is the extremely varying seeding density in the cylinder during the different phases in the engine cycle which covers a factor of 30 or even more.

The development of a tumble flow - a vortex with the axis of rotation perpendicular to the cylinder axis - is presented in Fig. 3 as a result of a PIV measurement. The field

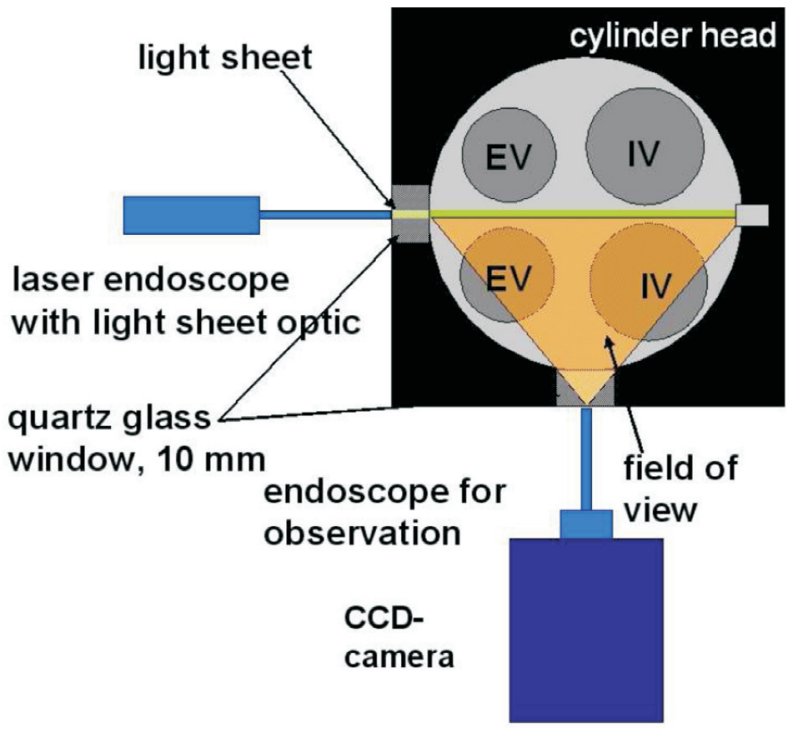

Fig. 2. Set-up for endoscopic PIV on a DI gasoline engine

Rys. 2. Metoda endoskopowa PIV w zastosowaniu do silnika o ZI $z$ wtryskiem bezpośrednim
Jednak, jeżeli trzeba zapewnić możliwość zapłonu mieszanki w silniku, musi być zastosowana specjalna, pomiarowa świeca zapłonowa. Obecnie jest dostępnych wiele wkładek optycznych do świec zapłonowych z różną liczbą światłowodów, kątów i obszarów obserwacji przeznaczonych do różnych zastosowań.

W większości czujniki światłowodowe są używane do wykrywania samorzutnego promieniowania płomienia silnikowego lub iskry zapłonowej wewnątrz komory spalania. Jednak ostatnie rozwiązania umożliwiają pomiary absorpcji i pomiary oparte na technice LIF przez światłowody umieszczone w świecy zapłonowej.

Główną zaletą wykorzystania istniejących otworów jest łatwość, z jaką można uzyskać dostęp optyczny od czasu, gdy badawcze świece zapłonowe dostarcza wielu producentów sprzętu pomiarowego. Ponadto pomiary mogą być prowadzone w każdym lub wszystkich cylindrach jednocześnie i nie są ograniczone do cylindrów mających uprzywilejowane miejsce, np. na końcu bloku. Występuje jedna niedogodność wynikająca $\mathrm{z}$ tego, że dostęp jest określony przez miejsce umieszczenia świecy zapłonowej i dlatego jest możliwy tylko jeden dostęp do cylindra.

\section{Diagnostyka optyczna w rozwoju systemów spalania}

Badania pól przepływu czynnika w cylindrze prowadzi się z wykorzystaniem metody PIV, w wielu przypadkach w silnikach z dostępem optycznym dużych rozmiarów. Metoda PIV z wykorzystaniem techniki endoskopowej została wprowadzona do handlu przez firmę LaVision ok. 2001 roku. Dierksheide $\mathrm{i}$ in. [5] opublikował wyczerpujący artykuł dotyczący konstrukcji endoskopu laserowego do oświetlenia i endoskopu obserwacyjnego do rejestracji zdjęć pola prędkości.

Typowy układ endoskopowej metody PIV dla silnika o ZI z wtryskiem bezpośrednim pokazano na rys. 2. Oba endoskopy mają średnicę zewnętrzną $8 \mathrm{~mm}$ i są umieszczone w adapterze z oknem opisanym w rozdz. 2. Cząsteczki posiewu stanowią krople oleju wytwarzane przez aerozolowy generator i nie powodują uszkodzenia silnika. Występuje jednak problem dużego zróżnicowania gęstości posiewu (nawet ponad 30-krotnego) w różnych fazach cyklu silnikowego.

Powstawanie przepływu beczkowego - wiru o osi prostopadłej do osi cylindra - przedstawiono na rys. 3, jako rezultat pomiarów PIV. Pole widzenia obejmuje całą średnicę cylindra. Stwierdzono, że tego rodzaju przepływ wirowy ma zasadnicze znaczenie dla stabilizacji powstawania palnej mieszanki przemieszczającej się w kierunku świecy zapłonowej (szczegóły zob. Hentschel i in. [1]).

Techniki endoskopowe do badania tworzenia się strugi wtryskiwanego paliwa i spalania w silnikach o ZS stosuje się od wczesnych lat 80. XX w., co opisują Cartellieri i Werlberger [6]. Oświetlenie strugi paliwa realizowano przez lampę błyskową, a zdjęcia były nagrywane kamerą do szybkiego filmowania na kolorowym, negatywowym filmie $16 \mathrm{~mm}$. W takiej konfiguracji można było rejestrować tylko jeden pojedynczy wtrysk, a wywołanie filmu trwało kilka dni. Dopiero gdy ok. 10 lat temu stał się dostępny laser impulsowy 
of view covers the entire cylinder bore. This tumble flow has found to be essential to stabilise the formation of an ignitable mixture on its way to the spark plug (for details see Hentschel et al. [1]).

Endoscopic techniques to investigate spray formation and combustion in diesel engines have been in use since the early 80th XX cent. as reported by Cartellieri and Werlberger [6]. Illumination of fuel sprays was provided by a flash bulb and the images were recorded with a high-speed movie camera on $16 \mathrm{~mm}$ colour-reversal film. In their set-up just one single injection event could be analysed and it took some days to get the processed film. Only when high-power pulsed laser and highly sensitive and fast CMOS-sensors became available about one decade ago crank angle synchronised analysis of a nearly unlimited number of engine cycles is achieved as a practical tool for combustion process development of DI gasoline and diesel engines.

Stroboscopic investigation of periodic events on internal combustion engines recorded by digital cameras such as spray formation have been reported by several authors, e.g. by Alt [7]. For time-resolved studies of transient events such as cyclic variation of spray propagation or knocking processes high-speed video techniques have to be applied with framing rates of many $\mathrm{kHz}$ or even higher. At these high framing rates the exposure time is rather short and bright illumination is required by appropriate high-power lasers.

In our experiments illumination of the spray inside the combustion chamber is performed with a high-power frequency-doubled solid-state Nd:YLF laser emitting light pulses in the green $(527 \mathrm{~nm})$ with about $200 \mathrm{~ns}$ duration. The light is guided by an optical fibre to the engine and illuminates a part of the combustion chamber via a sapphire window like a flood-light projector. The laser is triggered by the video camera and emits one light pulse per frame with an energy of about $1 \mathrm{~mJ}$. In this arrangement the spray images are taken by a Vision Research Phantom VII camera provided with a colour sensitive chip. An endoscope was used in front of the camera with an aperture angle of the optical system of about $60^{\circ}$. Thus, most of the combustion chamber can be observed. Cooling of the endoscope is essential to avoid damage of the endoscope optics by the high temperature during combustion and it is ensured by compressed air through internal channels in the endoscope tube.

Figure 4 shows a sequence of frames taken from a singe fuel injection process. The engine was operated in a fired mode at part load to ensure the correct thermal conditions. One image was taken every degree crank angle. Fuel injection takes place during the induction stroke to prepare a homogeneous DI combustion process. The fuel enters the combustion chamber from top right. In the first row of Fig. 4 the start of injection is presented, whereas the second row shows the end of the injection process. Due to the short duration of the laser light pulses no blurring occurs despite of the high velocity of the fuel droplets. The formation of the spray and its penetration into the combustion chamber can be observed in detail and relevant information is achieved about the correct timing of fuel injection. o dużej mocy oraz szybkie przetworniki sygnału świetlnego CMOS (ang. Complementary Metal Oxide Semiconductor, układ wielu elementów światłoczułych wykonany w technologii CMOS - przyp.tłum.), wówczas prawie nieograniczona liczba cykli rejestrowana synchronicznie z obrotami wału korbowego stała się praktycznym narzędziem do prac nad optymalizacją spalania w silnikach z wtryskiem bezpośrednim o ZS i ZI.

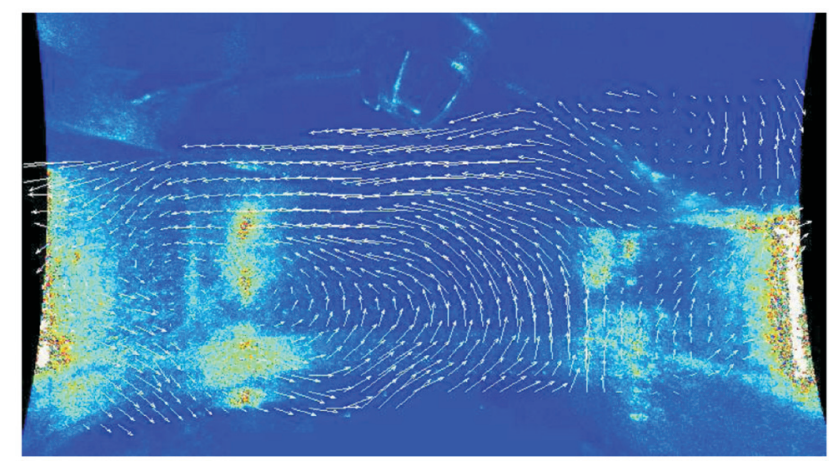

Fig. 3. Tumble flow development in the central cross section of the cylinder during the compression stroke

Rys. 3. Tworzenie się wiru beczkowego w środkowym przekroju cylindra podczas suwu sprężania

Badania stroboskopowe procesów powtarzalnych w silnikach spalinowych rejestrowanych kamerami cyfrowymi były omawiane przez wielu autorów, m.in. przez Alta [7]. W badaniach dynamicznych procesów przejściowych, jak cykliczna nierównomierność rozprzestrzeniania się strugi paliwa lub spalanie stukowe, należy stosować techniki szybkiego filmowania $\mathrm{z}$ częstotliwością naświetlania wielu kHz lub nawet większą. Przy tak dużych szybkościach filmowania czas naświetlania pojedynczego zdjęcia jest krótki, co wymaga jasnego oświetlenia przez zastosowanie odpowiedniego lasera o dużej mocy.

W naszych badaniach oświetlenie strugi paliwa w komorze spalania wykonuje się dwuimpulsowym laserem dużej mocy, opartym na ciele stałym typu Nd:YLF (neodymowy na bazie fluorku litowo-itrowego - przyp. thum.), emitującym impulsy światła zielonego $(\Lambda=527 \mathrm{~nm})$ o czasie trwania ok. 200 ns. Światło jest przekazywane przez światłowód do silnika i oświetla fragment komory spalania przez okno ze szkła szafirowego jak reflektor szerokostrumieniowy. Laser jest wysterowany przez kamerę filmującą i emituje jeden impuls świetlny na jedną klatkę zdjęciową z energią ok. 1 $\mathrm{mJ}$. W tej konfiguracji zdjęcia strugi wtryskiwanego paliwa były wykonywane kamerą Vision Research Phantom VII wyposażoną w kolorową matrycę. Endoskop zamontowano z przodu kamery, a kąt obserwacji systemu optycznego wynosił ok. $60^{\circ}$. Dzięki temu możliwa była obserwacja większej części komory spalania. Zasadnicze znaczenie dla zabezpieczenia układu optycznego endoskopu przed zniszczeniem przez wysoką temperaturę w czasie spalania ma chłodzenie endoskopu, które jest zapewnione przez sprężone powietrze przedostające się przez wewnętrzne kanały w osłonie endoskopu. 

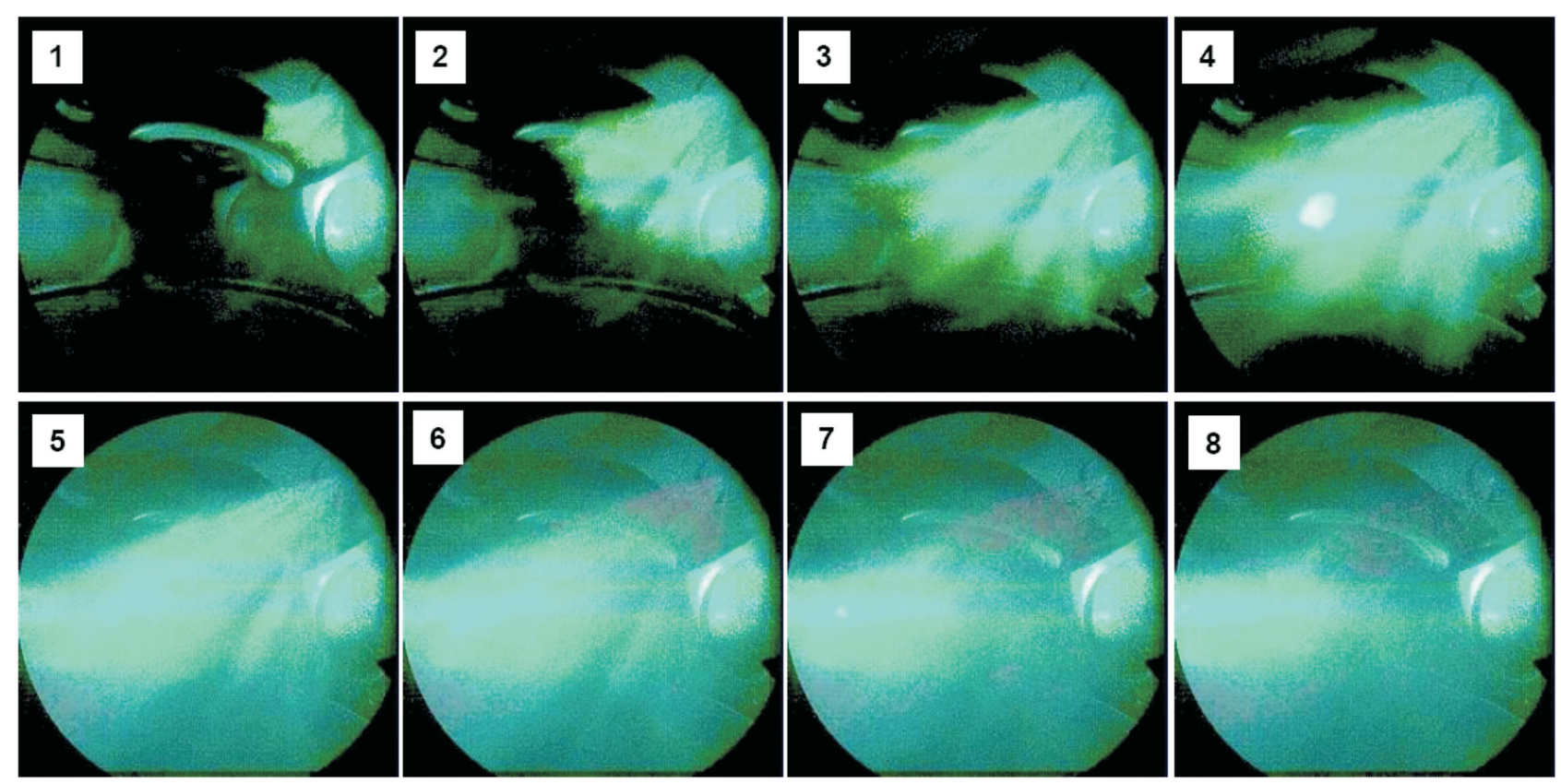

Fig. 4. Endoscopic investigation of fuel injection in a modern DI gasoline engine; start of fuel injection (top row) and end of fuel injection (bottom row)

Rys. 4. Endoskopowe badania wtrysku paliwa w nowoczesnych silnikach o ZI z wtryskiem bezpośrednim; poczatek wtrysku (zdjęcia górne), koniec wtrysku paliwa (zdjęcia dolne)

The formation of a homogeneous mixture after early fuel injection was verified by LIF investigations. The aromatic content of the standard fuel Euro Super used in these experiments was exited by UV laser light coming from a frequency quadrupled Nd:YAG laser at $266 \mathrm{~nm}$. The light pulse enters the combustion chamber via a small window mounted in the cylinder head below the exhaust valves and a vertical light sheet was formed. Fluorescence was observed perpendicular to the plane of illumination 5 by a specially designed UV-endoscope with a high light transmittance in the UV. The engine under study was motored at low speed and injection was provided according to full load operation. A fired operation was not possible in this case because the UV endoscope was not equipped with cooling facilities. The
Na rysunku 4 pokazano sekwencję zdjęć wykonanych dla pojedynczego procesu wtrysku. Silnik pracował na obciążeniu częściowym, żeby zapewnić odpowiednie warunki cieplne. Zdjęcia wykonywane były co $1^{\circ} \mathrm{OWK}$. Wtrysk paliwa odbywał się podczas suwu dolotu, w celu przygotowania mieszanki homogenicznej do spalania. Paliwo dostaje się do komory spalania od góry prawej strony zdjęcia. W pierwszym rzędzie na rys. 4 pokazano początek wtrysku, natomiast $\mathrm{w}$ drugim koniec procesu wtrysku. Odpowiednio do krótkiego czasu trwania impulsu oświetlenia laserowego nie pojawia się rozmycie obrazu, mimo dużej prędkości kropel paliwa. Tworzenie się strugi paliwa i jej penetracja w głąb komory spalania może być szczegółowo obserwowane, a przez skojarzenie z czasem wtrysku można uzyskać potrzebne informacje.

UV endoscope/endoskop na zakres $U V$

spark plug/świeca zapłonowa intake valve/zawór dolotowy exhaust valve/zawór wylotowy injector/wtryskiwacz sapphire window/okno szafirowe BTDC/przed GMP

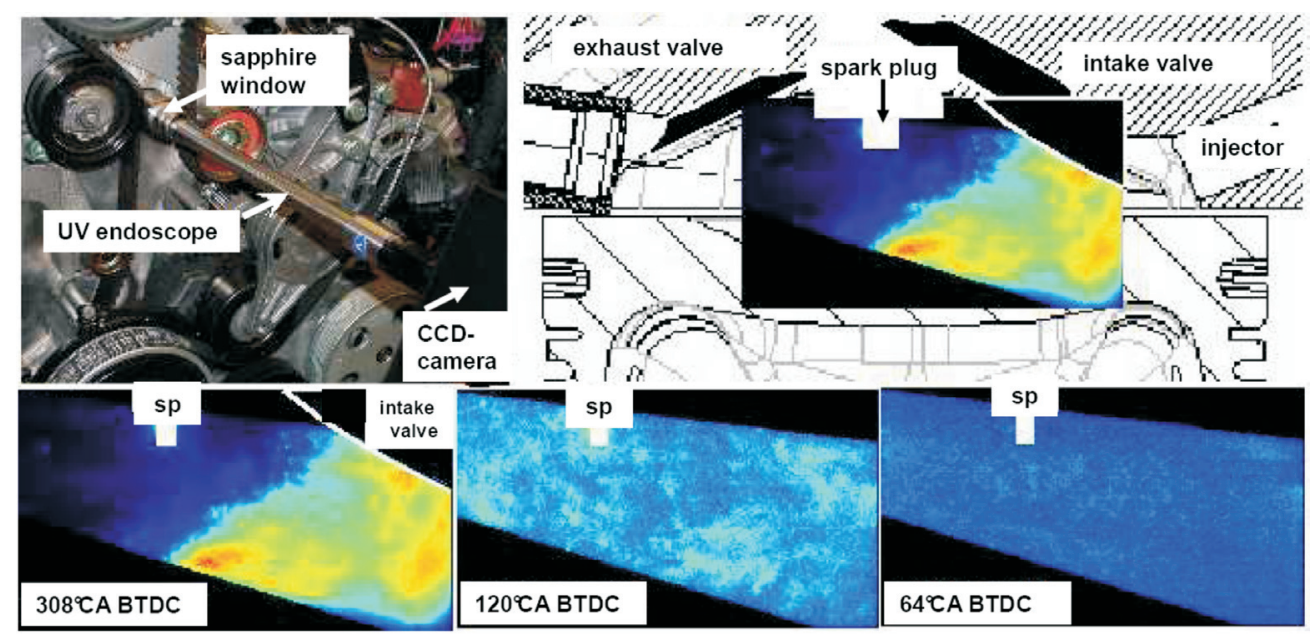

Fig. 5. UV endoscopic LIF investigation of fuel homogenisation

Rys. 5. Badania typu LIF homogenizacji paliwa z wykorzystaniem endoskopu na zakres promieniowania UV 
full diameter of the endoscope tube was used for the imaging system to provide a sufficient optical aperture to achieve a F-number of the endoscope of about 22 for UV light. The images were taken with an intensified CCD camera. In the top row of Fig. 5 the location of the endoscope in the gable section of the pent-roof combustion chamber (left) and a sketch of the field of view (right) is shown. The spray penetrates from top right to bottom left. In the bottom row 3 stages of the homogenisation process are displayed: Left, during injection with liquid fuel in red and yellow colours; middle, during evaporation with remaining tiny droplets; and right, nearly perfectly homogenised mixture. Injection timing together with the in-cylinder flow field interact perfect to obtain a homogeneous mixture at the time of ignition. It is not possible to get quantitative information about the airfuel-mixture by LIF with standard fuel.

A fibre optics spark plug sensor from LaVision, integrated into a spark plug, allows crank angle resolved measurement of the fuel concentration. Derived from this quantity, the air-fuel ratio - the lambda $(\lambda)$ value - is achieved directly in the combustion chamber of internal combustion engines; see Berg et al. [8,9]. The sensor replaces the standard spark plug, which means that no modifications to the engine are required for its installation. The ignition capability of the spark plug is maintained. The principle of the technique is shown in Fig. 6. The sensor makes use of the property of

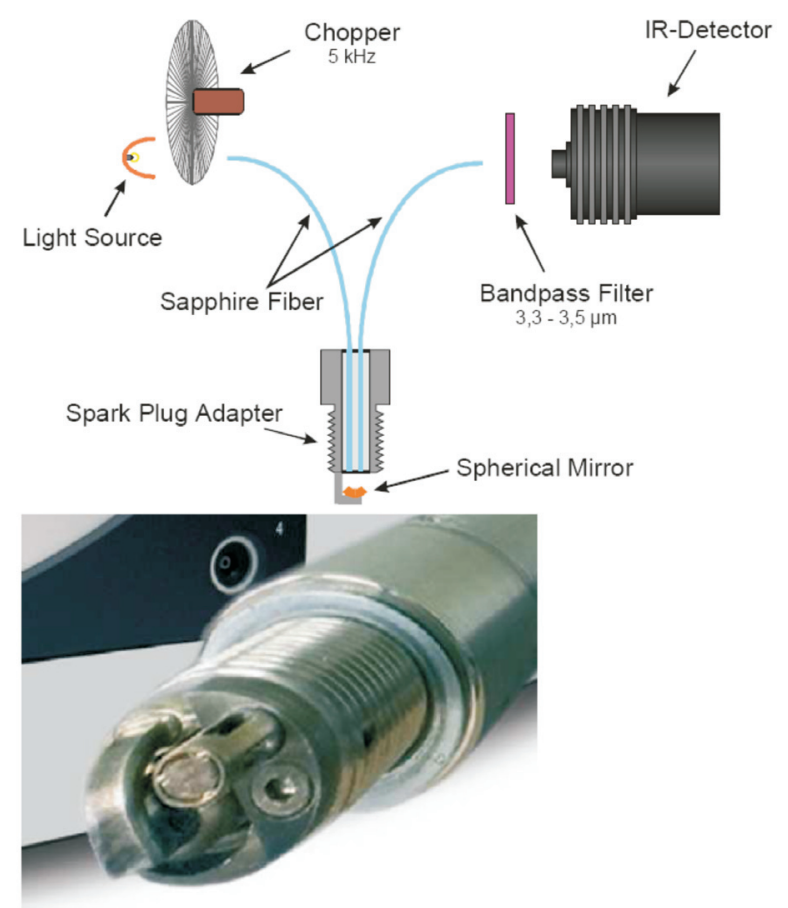

IR-Detector/czujnik promieniowania Spark Plug Adapter/adapter podczerwonego

Bandpass Filter 3.3-3.5 $\mu \mathrm{m} /$ filtr waskoprzepustowy świecy zapłonowej Chopper $5 \mathrm{kHz} /$ tarcza znacznika $5 \mathrm{kHz}$ Light Source/źródto światta

Sapphire Fiber/światłowód szafirowy Spherical Mirror/kuliste lustro

Fig. 6. Schematic set-up for the mid-infrared absorption probe (top) and view on the spark plug sensor tip (bottom)

Rys. 6. Schemat uktadu do pomiaru promieniowania $w$ zakresie podczerwonym (góra) $i$ widok czujnika $w$ świecy
Tworzenie mieszanki homogenicznej po wczesnym wtrysku paliwa było weryfikowane badaniami typu LIF. Węglowodory aromatyczne standardowego paliwa Euro Super zastosowanego w tych badaniach były wzbudzane przez ultrafioletowe światło laserowe emitowane przez laser neodymowy typu YAG (ang. Yttrium Aluminum Garnet, granat itrowo-aluminiowy - przyp. tłum.) przy długości fali $266 \mathrm{~mm} \mathrm{z}$ 4-krotnie zwiększona częstotliwością. Impuls świetlny dostaje się do komory spalania przez małe okno zamontowane w głowicy cylindrowej poniżej zaworu wylotowego i tworzy pionową płaszczyznę świetlną. Przez specjalnie skonstruowany endoskop z dużą transmitancją światła ultrafioletowego obserwowano fluorescencję w płaszczyźnie prostopadłej do powierzchni oświetlenia. Badany silnik był napędzany przy małej prędkości obrotowej, a wtrysk paliwa był odpowiedni do pracy silnika na pełnym obciążeniu. Praca silnika ze spalaniem w tym przypadku nie była możliwa, ponieważ endoskop na zakres UV nie był wyposażony w możliwości chłodzenia. Pełnowymiarowa osłona endoskopu była użyta do systemu zdjęciowego dla zabezpieczenia odpowiedniego optycznego kąta obserwacji i liczby przesłony endoskopu $\mathrm{F}^{1)}$ ok. 22 dla światła ultrafioletowego. Zdjęcia były wykonywane kamerą typu CCD (matryca kamery, ang. Charge Coupled Device - przyp. thum.) ze wzmacniaczem obrazu. W górnej części rys. 5 pokazano umiejscowienie endoskopu w górnej części daszkowej komory spalania (strona lewa) i zarys pola obserwacji. Struga paliwa rozprzestrzenia się od góry prawej strony do dołu lewej strony. W dolnym rzędzie (rys. 5) pokazano 3 etapy procesu homogenizacji: rys. lewy - podczas wtrysku ciekłego paliwa w kolorach czerwonym i żółtym, w środku - podczas odparowania z pozostającymi malutkimi kroplami, po prawej - prawie doskonale zhomogenizowana mieszanka. Wyprzedzenie wtrysku paliwa razem z działaniem pola przepływów wewnątrzcylindrowych doskonale wzajemnie oddziaływują na uzyskanie mieszanki homogenicznej w chwili zapłonu. Nie jest możliwe uzyskanie informacji ilościowych dotyczących jakości mieszanki paliwowo-powietrznej, gdy używa się systemu LIF z paliwem standardowym.

Czujnik światłowodowy w świecy zapłonowej firmy LaVision, zintegrowany ze świecą zapłonową, umożliwia pomiary stężenia paliwa w funkcji kąta OWK. Z tych wartości wyznacza się wartość współczynnika nadmiaru powietrza $\lambda \mathrm{w}$ komorze spalania silnika spalinowego (por. Berg i in. [9]). Czujnik umieszcza się w miejscu standardowej świecy zapłonowej, co oznacza, że nie wymaga on żadnej modyfikacji silnika. Zdolność do zapłonu świecy zapłonowej pozostaje utrzymana. Zasada konstrukcyjna jest pokazana na rys. 6. Czujnik wykorzystuje właściwość silnej absorpcji promieniowania podczerwonego przy długości fali $\Lambda=3,4 \mu \mathrm{m}$ wszystkich węglowodorów. Podczerwone światło ze źródła pulsacyjnego jest przesyłane do światło-

1) Liczba przesłony charakteryzuje ilość światła przepuszczanego do wnętrza obiektywu przy danym ustawieniu przysłony. Liczba ta jest odwrotnością wielkości otworu względnego obiektywu, co oznacza, że większa liczba przesłony oznacza mniejszą ilość przepuszczanego światła (przyp. tłum.). 
all hydrocarbons to absorb infrared radiation strongly at a wavelength of approximately $3.4 \mu \mathrm{m}$. Infrared light from a pulsed source is coupled into an optical fibre. The fibre ends at the tip of a modified spark plug where it passes through the air-fuel mixture in the combustion chamber. A spherical mirror reflects the light back into a second receiving fibre which transports the light onto a Peltier cooled $\mathrm{HgCdTe}$ infrared detector after passing through an optical band pass filter. The sensor electronics records this signal at a frequency of up to 30,000 measuring points per second. Thus, sub crank angle temporal resolution is achieved. The resulting fuel density values are converted to lambda $(\lambda)$ values by a sophisticated calculation procedure, see Kallmeyer et al. [10].

A typical result of a measurement with the optical spark plug sensor is shown in Fig. 7. The engine was motored and the time of end of injection (EOI) was varied between $35^{\circ}$ $\mathrm{CA}$ and $65^{\circ} \mathrm{CA}$ BTDC. All $\lambda$-value curves come from the very lean, reach a certain value in the rich and level out at $\lambda$ values between 0.8 and 1.4. A mixture cloud is formed and shifted to the spark plug by the in-cylinder flow which is in interaction with the piston movement. In this experimental case best conditions to achieve a reliable ignition are given for an EOI between 50 and $60^{\circ} \mathrm{CA}$ BTDC; see the marked area in Fig. 7. For more experimental results achieved under fired conditions in homogeneous and stratified operation see Kallmeyer et al. [10]

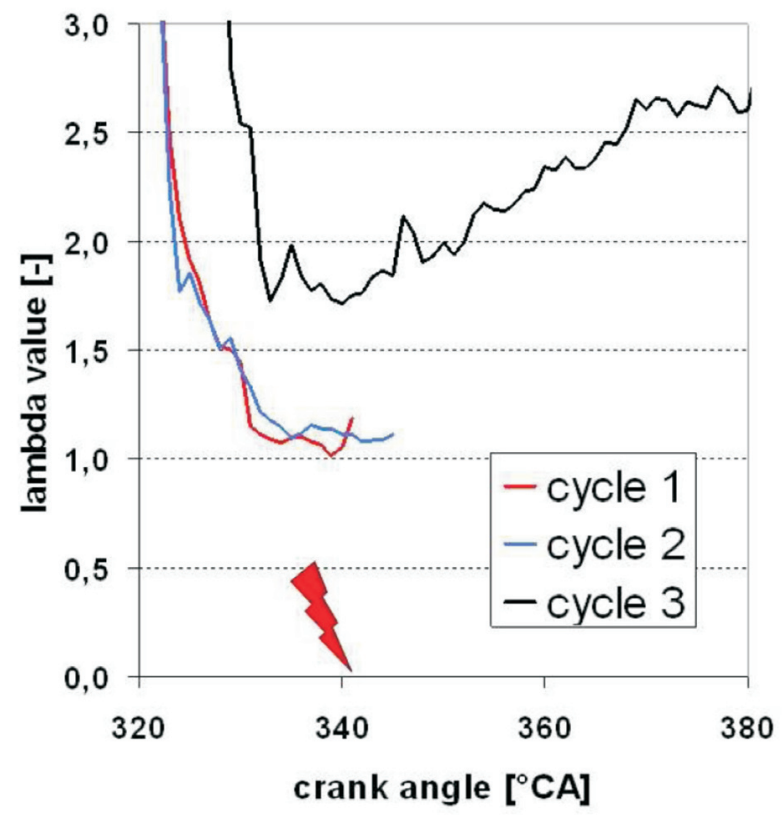

Fig. 8. Single cycle temporal $\lambda$-value development

Rys. 8. Zmiany bieżacych wartości współczynnika $\lambda$ w pojedynczym cyklu

The temporal development of the $\lambda$-value of three single cycles is shown in Fig. 8. The engine was operated lean in a stratified mode and the global $\lambda$-value was 2.7 . The injection timing was set to provide an instable engine operation. Cycle 1 and 2 show a regular combustion after a mixture processing which results in a $\lambda$-value around 1 at the time of ignition. The measurement was interrupted when the flame passes the wodu. Światłowód kończy się na czole przekonstruowanej świecy zapłonowej, skąd światło przedostaje się do komory spalania przez mieszankę paliwowo-powietrzną. Kuliste lustro odbija promieniowanie $\mathrm{z}$ powrotem do drugiego światłowodu odbiorczego, który przesyła światło do chłodzonego czujnika Peltiera HgCdTe światła podczerwonego, przechodząc przez wąskoprzepustowy filtr optyczny. Elektronika czujnika rejestruje ten sygnał z częstotliwością do 30000 punktów pomiarowych na sekundę. W ten sposób uzyskuje się rozdzielczość zbliżoną do stopnia obrotu wału korbowego. Wynikająca stąd wartość stężenia paliwa zostaje przeliczona na wartość $\lambda$ dzięki zaawansowanej procedurze obliczeniowej (por. Kallmeyer i in. [10]).

Typowy wynik pomiarów czujnikiem optycznym w świecy zapłonowej pokazano na rys. 7. Silnik był napędzany, a czas końca wtrysku (EOI) był zmieniany w zakresie 35 do $65^{\circ}$ OWK przed GMP. Wszystkie krzywe współczynnika $\lambda$ schodzą od mieszanki bardzo ubogiej, osiągają pewną wartość w zakresie mieszanki bogatej i stabilizują się na

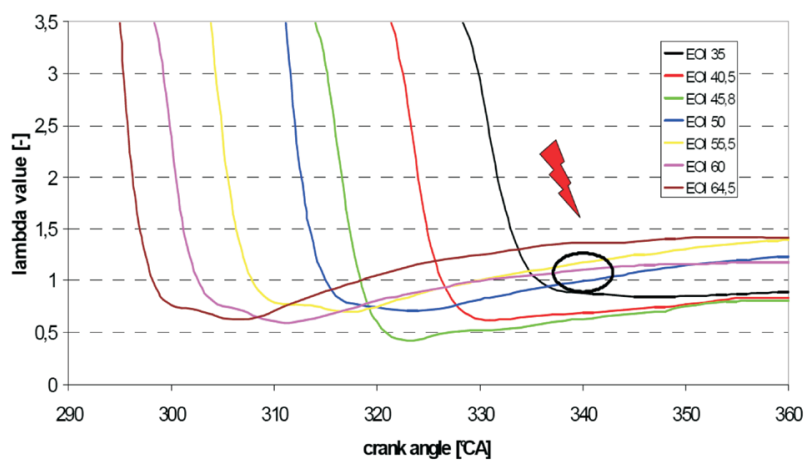

Fig. 7. Temporal $\lambda$-value development at different injection timings, measured by an optical spark plug sensor 6

Rys. 7. Zmiany bieżacych wartości wspótczynnika $\lambda$ przy różnych czasach wtrysku, mierzone przez optyczny czujnik w świecy zapłonowej

wartościach pomiędzy 0,8 i 1,4 . Chmura mieszanki jest formowana i przemieszczana w kierunku świecy zapłonowej przez przepływy wewnątrzcylindrowe, które są związane $\mathrm{z}$ ruchem tłoka. W tym przykładzie badawczym najlepsze warunki do uzyskania niezawodnego zapłonu występują dla końca wtrysku pomiędzy 50 i $60^{\circ} \mathrm{OWK}$ przed GMP zob. zaznaczony obszar na rys. 7 . Więcej wyników badań uzyskanych w silniku ze spalaniem w warunkach pracy na mieszance jednorodnej i uwarstwionej zawiera praca Kallmeyera i in. [10].

Przebieg wartości $\lambda$ w zależności od czasu dla 3 pojedynczych cykli roboczych pokazano na rys. 8 . Silnik pracował na uwarstwionej mieszance ubogiej o średniej wartości $\lambda=2,7$. Wyprzedzenie wtrysku dobrano tak, aby zabezpieczyć silnik przed niestabilną pracą. Cykle 1 i 2 pokazują regularne spalanie po procesie tworzenia mieszanki, co skutkuje wartością $\lambda$ ok. $1 \mathrm{w}$ chwili zapłonu. Pomiary były przerywane, kiedy pod czujnikiem przemieszczał się płomień. W cylindrze 3 mieszanka była zbyt uboga do zapłonu. Po wypadnięciu zapłonu chmura mieszanki zanikła i ostatecznie zmierzona wartość $\lambda$ zbiegła się z wartością średnią w całym cylindrze. 
sensor. In cycle 3 the mixture was too lean to be ignitable. After the failed ignition the mixture cloud disappears and finally the measured $\lambda$-value converges to the global $\lambda$-value in the combustion chamber. Thus, the engine misfire could have been explained by the analysis of the local mixture formation at the spark plug. This example shows the high sensitivity of this new probe technique.

The combustion chamber data measured directly at the spark plug give detailed information about the ignitability of the cylinder charge and provide engine developers with key characteristic values of in-cylinder events.

To further increase the performance and the output power of modern DI gasoline engines downsizing and high-pressure supercharging are commonly used. A possible problem of high-pressure supercharging at full load operation is the appearance of unwanted pre-ignition in the free mixture
Tak więc wypadnięcie zapłonu można wytłumaczyć na podstawie analizy lokalnego tworzenia mieszanki przy świecy zapłonowej. Ten przykład pokazuje dużą czułość tej nowej techniki pomiarowej.

Dane mierzone w komorze spalania bezpośrednio na świecy zapłonowej dostarczają szczegółowej informacji o zapalności ładunku znajdującego się w cylindrze i są dla konstruktorów silników kluczowymi wartościami charakterystycznymi dla zjawisk występujących wewnątrz cylindrów.

W celu dalszego zwiększania wskaźników pracy i mocy nowoczesnych silników o ZI z wtryskiem bezpośrednim stosowany jest powszechnie tzw. downsizing i doładowanie wysokociśnieniowe. W przypadku doładowania wysokociśnieniowego i pracy silnika na pełnym obciążeniu możliwe jest pojawienie się nieoczekiwanego, przedwczesnego samozapłonu. Charakteryzuje się on dużymi ciśnieniami w cone number (direction)/ numer stożka (kierunek) cylinder pressure/ciśnienie $w$ cylindrze

TOI (Time of ignition)/ chwila zapłonu exhaust/wylot intake/dolot

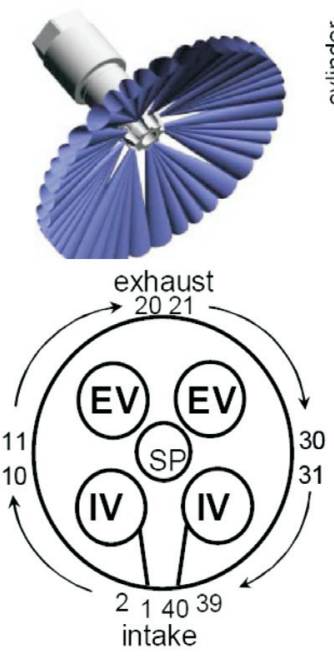

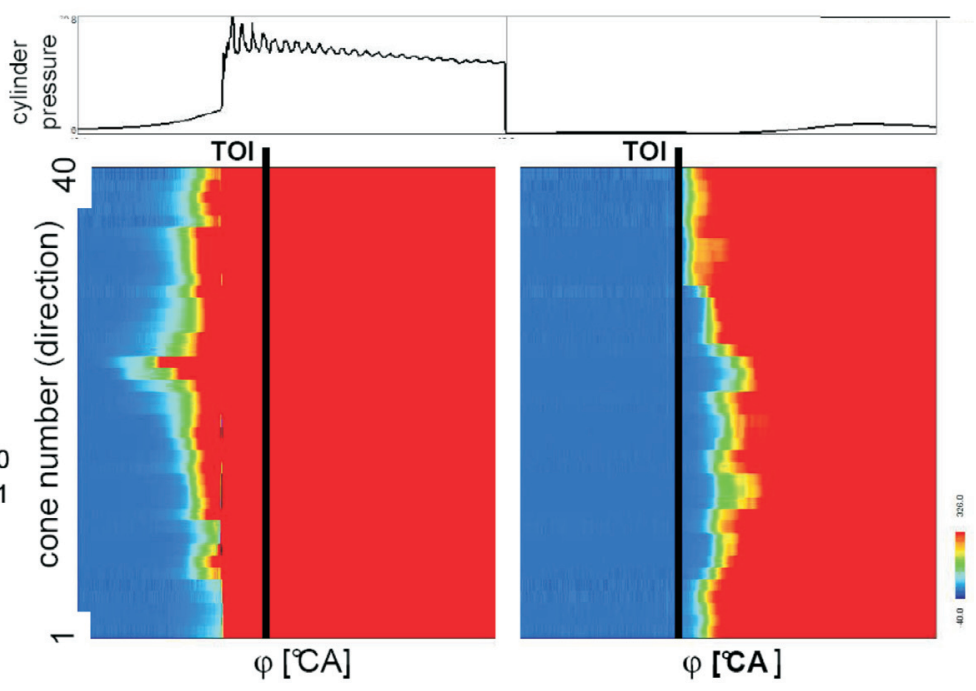

Fig. 9. Light signals for an engine cycle with pre-ignition (middle) and with regular ignition and combustion (right) and related pressure traces. Red indicates high luminosity

Rys. 9. Sygnały świetlne dla cyklu silnika z przedwczesnym zapłonem (środek), z regularnym zapłonem i spalaniem (prawy) oraz odpowiednie przebiegi ciśnienia. Kolor czerwony oznacza duża luminancję

prior the time of ignition. This pre-ignition is characterised by high in-cylinder pressures and extremely high pressure gradients and may cause severe damages to the engine. To learn about the circumstances and to avoid these difficult phenomena detailed investigations were made. The challenging task while applying optical diagnostics on an engine with pre-ignition is that the optical access has to be extremely rugged to resist the high pressures of more than 250 bar and the extremely high pressure gradients. Two different approaches were adopted.

First, a spark plug based optical sensor system from AVL was used to detect the direction of the pre-ignition in the cylinder. This "VisioKnock" sensor described by Winklhofer et al. [11] records the flame radiation intensity within 40 narrow observation cones which cover the combustion chamber volume between spark plug and cylinder liner. The optical signals are resolved with high temporal resolution cylindrze i ekstremalnie dużymi gradientami ciśnienia, co może prowadzić do poważnych uszkodzeń silnika. Żeby rozpoznać te warunki i ustrzec się przed tym niebezpiecznym zjawiskiem, przeprowadzono badania szczegółowe. Trudnym zadaniem przy stosowaniu diagnostyki optycznej jest to, że dostęp optyczny musi być ekstremalnie odporny na duże ciśnienia powyżej 250 bar i bardzo duże gradienty ciśnienia. Zastosowano dwa różne rozwiązania.

W pierwszym wykorzystano umieszczony w świecy czujnik optyczny z firmy AVL do detekcji przedwczesnego spalania w cylindrze. Ten czujnik typu „VisioKnock” opisany przez Winklhofera i in. [11] rejestruje intensywność promieniowania płomienia w przestrzeni 40 wąskich stożków obserwacyjnych, które pokrywają przestrzeń komory spalania między świecą zapłonową a tuleją cylindrową. Sygnały optyczne są analizowane z dużą częstotliwością w zależności od kąta obrotu wału korbowego; wyniki przedstawiono na 
in a sub-crank angle regime and the results are displayed in diagrams showing the directionally resolved light emission for single engine cycles. See Schintzel et al. [12] for more applications. Figure 9 displays the optical sensor (top left) and the numbering of the optical observation cones (bottom left). In the results shown here the engine runs at low to medium engine speed and full load. A comparison of two selected single combustion cycles is presented. In a typical regular combustion cycle (right) the bright flame starts a few deg. CA after the time of ignition (TOI), whereas in case of a pronounced pre-ignition (middle) a bright flame covers the entire combustion chamber long before TOI. In addition, the related pressure traces shown above the light signals indicate the steep pressure rise at the beginning of the pre-ignition and the high absolute cylinder pressure level.

To get a clearer view of the location of the onset of pre-ignition endoscopic investigation were applied simultaneously. Without any additional illumination the flame luminescence was recorded with a high-speed video camera via an endoscope mounted in the front face of the engine; see LIF paragraph for the position of the sapphire window. The engine is operated again at full load and with high-pressure supercharging. Frames from two selected engine cycles are presented in Fig. 10. Timing is given in deg. CA ATDC of ignition. In the top row of Fig. 10 a regular ignition and combustion occurs; the ignition spark is clearly visible in the second frame. The third and fourth frame show the flame propagation and a small sooting area at the edge of one intake valve. This example corresponds to the normal combustion case of Fig. 9 right. A completely different combustion behaviour is shown in the bottom row. Combustion starts about $15^{\circ} \mathrm{CA}$ before TOI and the complete mixture is burning within a few deg CA before TOI. In detailed investigations with both of the described optical techniques we have tried to find out the locations where most probably the preignition wykresie pokazującym kierunkową analizę promieniowania światła dla pojedynczych cykli pracy silnika. Więcej przykładów zastosowania omawia Schintzel i in. [12]. Na rysunku 9 pokazano czujnik optyczny (po lewej stronie, na górze) i numeracje stożków obserwacyjnych (poniżej). Pokazane tutaj wyniki dotyczą pracy silnika przy małej i średniej prędkości obrotowej, przy pełnym obciążeniu. Porównano dwa wybrane cykle pracy silnika. W typowym, regularnym cyklu pracy (po stronie prawej) jasny płomień pojawia się kilka stopni OWK po chwili zapłonu (TOI), podczas gdy w przypadku wspomnianego przedwczesnego zapłonu (w środku rys.) świecący płomień pokrywa całą komorę spalania długo przed iskrą zapłonową. Dodatkowo, odpowiednie przebiegi ciśnienia pokazane powyżej wykazują postrzępiony wzrost ciśnienia na początku przedwczesnego zapłonu i wysoki poziom ciśnienia w cylindrze.

W celu uzyskania jaśniejszego poglądu odnośnie do miejsca powstawania przedwczesnego zapłonu, jednocześnie zostały przeprowadzone badania endoskopowe. Bez dodatkowego oświetlenia promieniowanie płomienia zostało zarejestrowane kamerą do szybkich zdjęć przez endoskop zamontowany z przodu silnika (por. sposób umieszczenia okna szafirowego w układzie LIF). Silnik ponownie utrzymywano na pełnym obciążeniu $\mathrm{z}$ doładowaniem wysokociśnieniowym. Zdjęcia z dwóch wybranych cykli roboczych pokazano na rys. 10. Fazy cyklu są podane w deg. OWK po GMP w suwie pracy. W górnym rzędzie na rys. 10 pojawia się regularny zapłon i spalanie; świeca zapłonowa jest wyraźnie widoczna na drugim zdjęciu. Trzecie i czwarte zdjęcie pokazują rozprzestrzenianie się płomienia i mały obszar tworzenia się sadzy na krawędzi jednego zaworu dolotowego. Ten przykład odpowiada przypadkowi normalnego spalania z rys. 9, części prawej. Całkowicie inny przebieg spalania pokazano w dolnej części rysunku. Spalanie zaczyna się ok. $15^{\circ} \mathrm{OWK}$ przed przeskokiem iskry i całą mieszankę ogarnia płomień w ignition spark/świeca zapłonowa ATDC/po GMP regular combustion/normalne spalanie pre-ignition/przedwczesny zapton

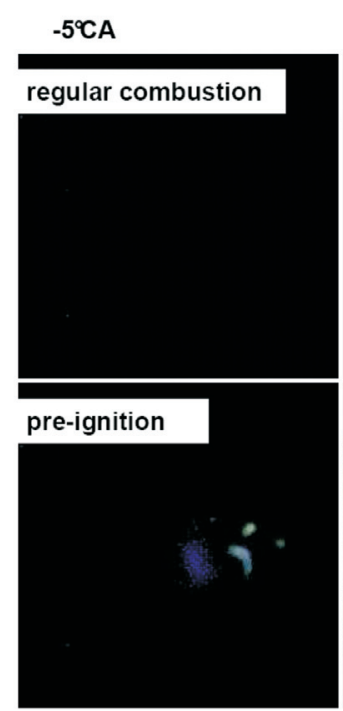

$8^{\circ} \mathrm{CA}$

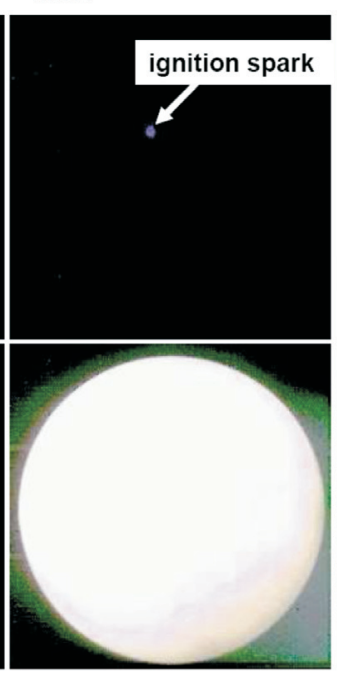

$22^{\circ} \mathrm{A}$

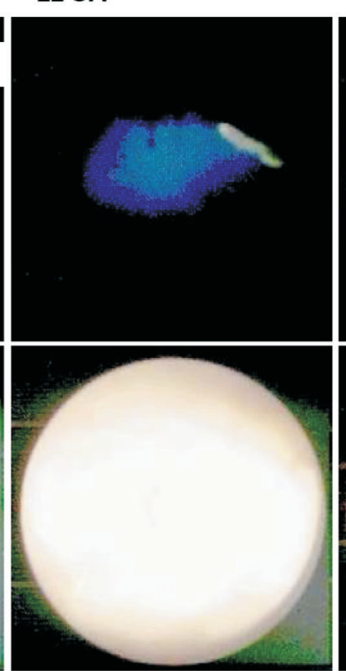

$35^{\circ} \mathrm{CA}$

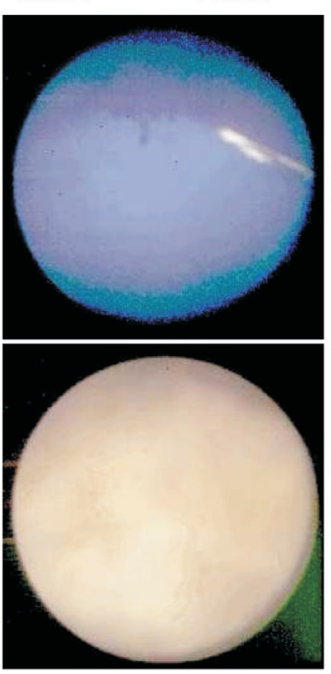

Fig. 10. Comparison of regular combustion (top row) and pre-ignition (bottom row) observed by endoscopic high-speed video; engine fired at full load with high-pressure supercharging

Rys. 10. Porównanie spalania normalnego (górna część rys.) i zapłonu przedwczesnego (dolna) rejestrowane kamera do szybkiego filmowania przez endoskop; silnik pracujacy na petnym obciażeniu z wysokim doładowaniem 
starts, and measures were examined to reduce the frequency of pre-ignition.

\section{Conclusion}

A discussion about the use of endoscopes for the analysis of in-cylinder processes in engine research and development has to balance the disadvantages and advantages.

Disadvantages of endoscopes are:

a) the high optical F-number results in a low light transmission efficiency ( standard lens $F=2$, endoscope $F=20-40$; this is a factor of greater 100 in light intensity);

b) endoscopes have a reduced optical resolution due to their small aperture;

c) they have a strong optical distortion due to their large viewing angle (fish-eye effect);

d) the plane of sharp focus has a hemispherical shape; the effective usable optical diameter (ratio of outer diameter of the tube to diameter of the optical system) is limited by illumination and cooling devices incorporated in the endoscope tube;

e) in practice illumination is not possible via internal fibres due to reflections on the combustion chamber windows which are indispensable to protect the endoscopes against the flames and the high in-cylinder pressures;

f) the optical system of commercial endoscopes will be destroyed at temperatures higher than $130^{\circ} \mathrm{C}$ and therefore cooling is strongly required for high load fired engine operation.

On the other hand the advantages of endoscopes are impressive:

a) just small optical access to the engine is required;

b) engine operation at high speed and high load is possible;

c) they are - in principle - easy to use and mostly no timeconsuming alignment is required;

d) they can be combined with all kinds of cameras (CCD, CMOS, High-Speed, PIV, UV-LIF, ...).

Endoscopes will become a standard tool for in-cylinder engine measurements with only minor modifications on production engines and without any operating restrictions of the engine. The most important request to the endoscope designers is to reduce the F-number to get brighter images at a given small outer diameter of the endoscope tube.

At present, a guideline for the use of endoscopes is: "Select endoscopes as large as possible and as small as necessary!"

Optical probes mounted in only small additional holes or in existing holes like the one for the spark plug will become more and more important. With the fibre optics spark plug sensor from LaVision a new generation of optical sensors is available which allows crank angle resolved measurements of the air-fuel ratio. The sensor hardware is being upgraded to measure the temporal concentration profiles of other incylinder specious.

Many of the experimental results from the optical diagnostics are used to assist and to validate CFD-simulations done in parallel and both together deliver complete information for the engine designer about the in-cylinder processes, ciągu kilku stopni OWK przed pojawieniem się iskry zapłonowej. W szczegółowych badaniach z wykorzystaniem obu omówionych optycznych technik badawczych podjęto próbę określenia miejsca powstawania przedwczesnego zapłonu i środków na zmniejszenie jego częstotliwości.

\section{Podsumowanie}

W dyskusji na temat zastosowania endoskopów do analizy procesów wewnątrzcylindrowych w badaniach silników spalinowych trzeba wyważyć ich wady i zalety. Wadami endoskopów są:

a) duża wartość liczby przesłony $\mathrm{F}$ powodująca małą transmisyjność światła (soczewki standardowe $\mathrm{F}=2$, endoskop $\mathrm{F}=20-40 ;$ tj. 100-krotne pogorszenie transmisyjności światła);

b) endoskopy mają zmniejszoną rozdzielczość optyczną ze względu na małą aperturęę);

c) wykazują bardzo duże zniekształcenie optyczne ze względu na duży kąt obserwacji (efekt „rybiego oka”);

d) powierzchnia ostrego obrazu w ognisku ma kształt półkulisty;

e) użyteczna średnica optyczna (stosunek zewnętrznej średnicy rurki endoskopu do średnicy układu optycznego) jest ograniczona przez układy oświetlające i chłodzące zintegrowane w endoskopie;

f) w praktyce nie jest możliwe oświetlanie przez wewnętrzne światłowody ze względu na odbicia na oknie do komory spalania, które są niezbędne do osłony endoskopów przed płomieniem i dużym ciśnieniem w cylindrze;

g) system optyczny endoskopów handlowych ulega zniszczeniu przy temperaturach powyżej $130^{\circ} \mathrm{C}$ i dlatego przy pracy silnika na dużych obciążeniach niezbędne jest jego chłodzenie.

Imponujące są zalety endoskopów:

a) wymagany jest tylko niewielki dostęp optyczny do silnika;

b) jest możliwa praca silnika przy dużej prędkości obrotowej i obciążeniu;

c) są - w zasadzie - łatwe do zastosowania, a ich regulacja nie jest czasochłonna;

d) mogą być skojarzone z wszystkimi rodzajami kamer (CCD, CMOS, High-Speed, PIV, UV-LIF, ...).

Endoskopy staną się standardowym narzędziem do pomiarów wewnątrz cylindrów silników spalinowych, wymagającym nieznacznych modyfikacji konstrukcyjnych w stosunku do silników seryjnych, nie wprowadzając przy tym żadnych ograniczeń w warunkach pracy silnika. Najważniejszym oczekiwaniem od konstruktorów endoskopów jest zmniejszenie liczby przesłony $\mathrm{F}$ w celu uzyskania jaśniejszych zdjęć przy określonej małej średnicy rurki endoskopowej. Obecnie wytyczna dla użytkowników endoskopów brzmi następująco: „,wybrać endoskop tak duży, jak to możliwe, i tak mały, jak to konieczne!”.

Czujniki optyczne montowane w małych, dodatkowych lub już istniejących otworach, takich jak otwór do świecy

2) Rozwartość układu optycznego, decydująca o jego zdolności rozdzielczej i jasności obrazu, rozumiana jako kąt pomiędzy skrajnymi promieniami stożkowej wiązki światła wchodzącej do układu optycznego (przyp. tłum.) 
and thus support further steps of optimisation of the combustion process of the Volkswagen $\mathrm{FSI}^{\circledR}$-engine.

Currently, a new research approach is made to develop highly sophisticated laser-optical diagnostic tools to better analyse in-cylinder processes such as the concentration of species and of state quantities. In this research project called MIMODIA (Ger.: Minimal Invasive MOtorische DIAgnostik, Eng.: minimal-invasive engine diagnostics) research facilities and industries work jointly together. The project is partly funded by the German Federal Ministry of Education and Research under the framework of "Optical Technologies". Finally, these optical sensors shall help to develop new engine concepts with reduced emissions and fuel consumption and thereby make a sustainable contribution to conserve the environment.

\section{Acknowledgement}

Part of the methods and results presented in this paper were achieved in research projects funded by regional and federal German government. This support is gratefully acknowledged. The author would like to thank Stefan Dankers, Felix Kallmeyer, Gerhard Ohmstede and Kay Schintzel from the Metrology Department and the Engine Research Department for their support.

Artykut recenzowany

\section{Bibliography/Literatura}

[1] Hentschel W., Block B., Hovestadt T., Meyer H., Ohmstede G., Richter V., Stiebels B., Winkler A.: Optical Diagnostics and CFD Simulations to Support the Combustion Process Development of the Volkswagen FSI Direct-Injection Gasoline Engine. SAE Technical Paper Series 2001-01-3648, 2001.

[2] Zhao H., Ladommatos N.: Engine Combustion Instrumentation and Diagnostics. Society of Automotive Engineers, Warrendale 2001, p.51.

[3] Knapp M., Beushausen V., Hentschel W., Manz P., Grünefeld G., Andresen P.: In-cylinder mixture formation analysis with spontaneous Raman scattering applied to a mass-production SI engine. SAE Technical Paper Series 970827, 1997.

[4] Richter M.,Axelsson B., Alden M.: Engine diagnostics using laser induced fluorescence signals collected through an endoscopic detection system, SAE Technical Paper Series 982465, 1998.

[5] Dierksheide U., Meyer P., Hovestadt T., Hentschel W.: Endoscopic 2D-PIV flow field measurements in IC engines. Exp. in Fluids 33 (2002), pp. 794-800.

[6] Cartellieri W. P., Werlberger P.: Investigation of Combustion in High Speed Direct Injection Diesel Engines Using a Novel High Speed Combustion Photography Technique. SAE Technical Paper Series 845008, 1984.

[7] Alt M., Quarg J.: Videoscopy as a development tool for air assisted direct injection of gasoline engines. Proc. 5th Int. Symp.on Internal Combustion Diagnostics, Baden-Baden, 6/7 June 02, p.243.

[8] Berg T., Voges H., Thiele O., Beushausen V., Hentschel W., Kallmeyer F.: Optical Sensors for Automotive Engine-Research Applications. Proc. IEEE-Sensors 2005 Conference, Irvine, CA, USA, 31. Okt.-3. Nov. 2005.

[9] Berg T., Beushausen V., Thiele O., Voges H.: Fibre Optical Spark Plug Sensor for the Optimisation of Engine Combustion Processes. MTZ Motortechnische Zeitschrift 67 (2006), vol. 6. zapłonowej, będą stawać się coraz ważniejsze. Dzięki czujnikowi światłowodowemu w świecy zapłonowej firmy LaVision dostępna jest nowa generacja pomiarów, która umożliwia dynamiczne wyznaczenie współczynnika nadmiaru powietrza w funkcji kąta OWK. Czujnik został rozbudowany do pomiaru chwilowej koncentracji innych cząsteczek w cylindrze.

Wiele wyników eksperymentalnych z diagnostyki optycznej jest wykorzystywanych do wspomagania i walidacji komputerowych symulacji CFD prowadzonych równolegle, i wspólnie tworzą całościowe informacje dla konstruktorów silników na temat procesów wewnatrzcylindrowych; w ten sposób wspomagają następne kroki optymalizacyjne procesu spalania w silniku FSI ${ }^{\circledR}$ firmy Volkswagen.

Obecnie podjęto nowy kierunek badań - opracowanie bardzo zaawansowanego optycznego, laserowego narzędzia diagnostycznego do lepszej analizy procesów wewnątrzcylindrowych, takich jak: stężenie cząstek i wskaźniki stanu. W tym projekcie badawczym, nazwanym MIMODIA (niem.: Minimal Invasive MOtorische DIAgnostik), wspólnie pracują jednostki badawcze i przemysłowe. Projekt jest częściowo finansowany przez Niemieckie Federalne Ministerstwo Edukacji i Badań pod nazwą „Technologie optyczne”. Ostatecznie takie czujniki optyczne powinny przyczynić się do rozwoju nowych koncepcji konstrukcyjnych silnika ze zmniejszoną emisją związków toksycznych i zmniejszonym zużyciem paliwa, i w ten sposób istotnie przyczynić się do ochrony środowiska naturalnego.

\section{Podziękowania}

Część metod i wyników przedstawionych w tym artykule uzyskano w ramach projektu badawczego finansowanego przez niemiecki rząd federalny i rząd krajowy. Autor dziękuje za okazaną pomoc panom: Stefanowi Dankersowi, Felixowi Kallmeyerowi, Gerhardowi Ohmstede i Kayowi Schintzelowi z Działu Pomiarów i Działu Badań Silników Spalinowych.

[10] Kallmeyer F., Dankers S., Hentschel W., Grosse G., Thiele O., Schulz C.: Bestimmung des lokalen Lambda-Wertes im FSI ${ }^{\circledR}$ -Motor mittels einer optischen Zündkerze. Haus der Technik, München; in: A. Leipertz (Hrsg.): "Motorische Verbrennung - Aktuelle Probleme und moderne Lösungsansätze" (VII. Tagung), Ber. zur Energie- und Verfahrenstechnik; Heft 7.1, Erlangen 2007, s. 207-219.

[11] Winklhofer E., Beidl C., Philipp H., Piock W.: Experiences with VisioFiber technologies in developing m odern combustion systems. Proc. 5th Int. Symp. on Internal Combustion Diagnostics, Baden-Baden, 6/7 June 2002, pp. 7-18.

[12] Schintzel K., Willand J.: Klopfphänomene am Beispiel ausgewählter Motoren der Volkswagen AG. In: Brill U. (ed.): Klopfregelung für Ottomotoren II; Haus der Technik, BerlinEssen 2006.

Mr. Werner Hentschel, DSc. - employee at Research and Development - Metrology Department in Volkswagen AG, Wolfsburg, Germany. Dr Werner Hentschel - pracownik Działu Badawczo-Rozwojowego firmy Volkswagen, Wolfsburg, Niemcy. e-mail: werner.hentschel@volkswagen.de 